\title{
Compound Prepositions Used by Iraqi EFL University Students
}

\author{
Ahmed Mohammed Ali Abu Humeid ${ }^{1}$ \\ ${ }^{1}$ College of Education for Human Sciences, University of Babylon, Babel, Iraq \\ Correspondence: Ahmed Mohammed Ali Abu Humeid, College of Education for Human Sciences, University of \\ Babylon, Babel, P.O. Box: 697 Al-Zahra Quarter Babylon, Iraq. E-mail: ahmedbabylonian@gmail.com
}

Received: January 20, 2013 Accepted: February 16, 2013 Online Published: March 25, 2013

doi:10.5539/ijel.v3n2p98

URL: http://dx.doi.org/10.5539/ijel.v3n2p98

\begin{abstract}
There is no logical reason why one compound preposition is right in a certain context, whereas another one is wrong. To use compound prepositions correctly is difficult because most of them have several functions. In addition, different prepositions have sometimes similar uses. Such prepositions cause difficulty to Iraqi EFL university students because syllabus designers and teachers do not concentrate on such sort of prepositions. This study aims at identifying and analyzing the errors Iraqi EFL university students encounter in using such prepositions and finding the reasons behind students' errors. A diagnostic test is designed and applied to a sample of 100 Iraqi EFL university students at their third year. In the light of the students' responses, it can be concluded that the majority of Iraqi EFL university students fail to recognize and produce such propositions. Moreover, they do not realize the function of such prepositions because they do not discern their meanings and most books of grammar do not list their meanings or uses. As such, the researcher uses Hornby (2006) to clarify their meanings. The subjects' errors are attributed to the following factors: (i) interlingual transfer, (ii) intralingual transfer, (iii) context of learning, and (iv) communication strategies.
\end{abstract}

Keywords: compound preposition, prepositional meaning, Iraqi EFL university student, error analysis

\section{Introduction}

They are common in English sentences. They are the prepositions that are composed of more than one word. They have several functions depending on the context in which they occur. Also, there is no logical reason why one compound preposition is right in a certain context, whereas another is wrong.

To use compound prepositions correctly is one of the serious problems faced by Iraqi EFL university students. The proper use of compound prepositions is difficult because most of them have several functions. Different prepositions have similar uses. For this reason, the researcher shows the meaning(s) of these propositions so as to enable EFL learners to employ them in their speaking and writing properly. So it is normal to commit mistakes.

This study aims at:

1. Identifying and analyzing the errors which Iraqi EFL university students are liable to make in using compound prepositions.

2. Giving a clearer rationale for the possible causes for such errors.

In view of the preceding aims, it is hypothesized that:

1) Most Iraqi EFL university students encounter difficulties in recognizing and producing compound prepositions.

2) Most of them do not distinguish the position of compound prepositions.

3) Most of them cannot identify the function of such prepositions.

4) Most of them generally flunk to acquire the proper use of compound prepositions.

There are some cross-cultural studies made on prepositions in general. One is between Persian and English by Mahmoodzadeh in 2012. Other studies try to give an account of the prepositions found in a particular language, like a study made by van de Vate in 2006 on Krio. Other papers try to tackle a specific issue in English prepositions, like a paper written by Meurant 2007. In addition, some articles focus on the translation of prepositions and the problems and solutions related to this process. An instance is a study presented by Shih 2012 and another article is given by Japkowicz \& Wiebe 2009. In computational linguistics, a group of studies 
are written on compound prepositions. Among which are Trawiński paper 2008 and Oliveira \& Garrão in 2009.

As such, this study is of importance because it is an error analysis study that is dedicated to Iraqi EFL university students and the problems they face in dealing with such prepositions. Furthermore, it gives a diagnostic analysis of the students' errors as no similar study is conducted on such type of prepositions.

\section{Research Design}

The procedure followed in this research can be summed up as follows:

1- Giving an account of compound prepositions depending on the literature in this field.

2- Designing a test and applying it to a number of students at the third year so as to find out the difficulties they encounter with this sort of prepositions.

3- Analyzing the results of the test, on the bases of which conclusions have been drawn.

This study is limited to 100 Iraqi EFL university students in their third year at the Department of English, College of Education for Human Sciences, University of Babylon during the academic year 2011-2012. Third year students are chosen because they are at advanced stage and they have studied this topic previously.

\section{Compound Prepositions}

Compound prepositions are the prepositions that encompass more than one word, especially when a noun or a noun phrase is both followed and preceded by single prepositions as in on account of (Crystal, 2003).

The boundary between simple and compound prepositions is not entirely explicit. Depending on orthography, separation is the easiest way to discriminate between them, but there are some irregularities such as writing into as one word and out of as two words. This emphasizes the idea of arbitrariness of the distinction between one and more than one word. The best way to discriminate between simple and compound prepositions is that a simple preposition is still identical in form to its correspondence adverb, whereas a compound preposition forfeits its final element when transferred to the function of adverb (apart from=apart), (Quirk et al., 1985, pp. 301-302).

Interestingly, some compound prepositions can be transferred to other parts of speech when dropping their final prepositions (e.g., instead, out [adverb]; because, except, in case [conjunction]; in front, on top [adverbials]) (Chalker, 1989, p. 216).

Another significant distinction to draw is between the terms: 'compound preposition' and 'prepositional phrase'. The former means the preposition that consists of more than one word and behaves just like a single preposition. The latter consists of the preposition + the prepositional complement, usually a noun phrase (e.g., in the garden) (Chalker 1989, p. 214).

Stageberg (1981, p. 169) states that prepositions are "words like of, in and to which are usually followed by a noun, noun phrase, personal pronoun, or noun-substitute called the object of the preposition. The unit of preposition-plus-object of preposition is called a prepositional phrase."

\section{1- George came with Ann.}

2- Janet jumped on the fence.

Grammarians classify English prepositions into different sorts. Palmer and Blandford (1976) subsume prepositions under simple prepositions which consist of single words (e.g., across, before, from) or group prepositions which consist of more than one word (e.g., according to, out of, because of). A number of two and three word phrases (e.g., in spite of, according to, apart from) behave like simple prepositions. (Roberts, 1956, p. 89) mentions that we spell these prepositions as separate words, but we use them as units, and it is simpler to consider them as single prepositions. Quirk et al., (1985) mention that most of these are subsumed under the following categories:

a) Adverb or preposition + preposition: along with, as for, away from, out of, up to.

b) Verb / adjective / conjunction / + preposition: owing to, due to, because of.

c) Preposition + noun + preposition: by means of, in comparison with, in front of.

In [c], which is by far the most numerous category, the noun in some compound prepositions is preceded by a definite or an indefinite article: in the light of, as a result of. In addition to compound prepositions, simple prepositions are composed of one word (ibid.).

Compound prepositions can be classified into two-word sequences and three-word ones. A and b categories can 
be classified under two-words sequences, whereas $\mathbf{c}$ can be classified as three-words sequences (ibid., p. 669).

There are some cases of lexicalization which have been accompanied historically by some syntactic restructuring. For instance, because of comes from by cause of and inside derives from in + side + of, (Huddleston, 1985, pp. 342-344).

Here is a list of some two-word sequences prepositions followed by another list of three-word prepositions. Then, prepositions are all mentioned by Quirk et al., (1985, pp. 669-671).To clarify them better, the researcher consults Hornby (2006) for their meaning(s) and add them against each compound preposition.

Table 1. Two-word prepositions (After Quirk et al., 1985, p. 669 \& Hornby 2006)

Up against: facing problems or opposition or in As per: in accordance with or as usual. a difficult situation.
As for: (i) used to start talking about somebody But for: if it were not for. or something, and (ii) regarding.
Except for: apart from or not including.
Apart from: (i) except for, (ii) in addition to, Aside from: except for or apart from. and (iii) as well as.
Away from: (i) distant from somebody or As from: used to show the time or date from something in space and time, and (ii) absent.
which something starts.

\begin{abstract}
Ahead of: (i) further forward in space and time than somebody or something, (ii) in front of somebody or something, and (iii) earlier than somebody or something.

Back of: behind something.

Exclusive of: not including somebody or something.

Instead of: in place of somebody or something.

Off of: (i) off and (ii) from.

Outside of: (i) apart from, (ii) not in a particular place, (iii)away from, (iv) not part of something, and $(\mathrm{v})$ on or to a place on the outside of something.
\end{abstract}

Upwards of: more than the amount or number mentioned.
According to: (i) as stated or reported by somebody or something, (ii) following, (iii) agreeing with, and (iv) depending on something.

Close to: in a position very near to something.

Due to: (i) caused by somebody or something and (ii) because of.

Next to: (i) Close to, (ii) in or into a position right beside somebody or something, (iii) following in order or importance after somebody or something, (iv) almost, and (v) in comparison with somebody or something.

Owing to: because of

Preparatory to: to prepare for.

Prior to: before something.
As of: (i) as from and (ii) as at a specified time.

Because of: for the reason that.

Devoid of: completely lacking something.

Inside of: (i) on or to the inner part of somebody or something, (ii) within somebody or something, and (iii) in less than the amount of time mentioned.

Irrespective of: (i) without considering something or being influenced by it and (ii) regardless of.

Out of: away from.

Regardless of: (i) paying no attention to somebody or something, and (ii) treating somebody or something as not being important.

Void of: devoid or completely lacking something.

As to: used when you are referring to something.

Contrary to: (i) different from something, and (ii) against something.

Near(er) to: (i) at a short distance, (ii) away from somebody or something, (iii) a short period of time from something used before a number to mean approximately, (iv) similar to somebody or something in quality and size, and (v) close to a particular state.

On to: (i) get in touch with, and (ii) realize the significance or intention of.

Preliminary to: it is an action or event that is done in preparation for something or happening before a more important action or event.

Previous to: (i) happening or existing before the 
Subsequent to: after or following.

Up to: (i) until, (ii) not more than, (iii) less than or equal to, (iv) incumbent on, (v) capable of or fit for, and (vi) occupied or busy with. event or object that somebody is talking about, and (ii) immediately before the time somebody is talking about.

Pursuant to: (i) according to, (ii) following a rule or law, and (iii) in accordance with.

Thanks to: something has happened because of somebody or something.

\footnotetext{
Along with: (i) in addition to somebody or Together with: (i) including, (ii) in addition to, something, and (ii) in the same way as and (iii) as well as. somebody or something.
}

Table 2. Three-word sequences prepositions (After Quirk et al., 1985, pp. 670-671 \& Hornby, 2006)

$$
\text { In+ noun+ of: }
$$

In aid of: in order to help somebody or something $=$ (in support of $)$.

In behalf of: in order to help somebody.

In charge of: having command.

In (the) face of: (i) as a result, and (ii) in spite of problems and difficulties $=($ despite $)$.

In front of: (i) ahead of, (ii) in the presence of, and (iii) confronting.

In lieu of: instead of.

In place of: instead of.

In quest of: seeking.

In search of: looking for somebody or something.

In view of: considering something $=$ (having regard to)
In back of: (i) on the back of, and (ii) as a result of an action or a success.

In case of: (i) if something happens, and (ii) in the event of.

In consequence of: as a result of something.

In favour of: (i) in support of, and (ii) in advantage of.

In (the) light of: after considering something.

In need of: requiring.

In (the) process of: (i) a series of things that are done in order to achieve a particular result, and (ii) with the time goes on.

In respect of: (i) concerning, (ii) in payment for something, (iii) as concerns, and (iv) with reference to.

In spite of: despite

\section{In+ noun+ with:}

In accordance with: according to.

In comparison with: compared to.

In conformity with: (i) following the rules of something, and (ii) confirming.

In line with: in (or not in) accordance with.
In common with: in the same way as somebody or something.

In compliance with: according to (a wish, command, etc.)

In contact with: the act of communicating with somebody regularly.

\section{By+ noun+ of:}

By dint of: by means of.

By virtue of: (i) by means of, and (ii) because of.
By means of: by the agency or instrumentality of a thing or action.

By way of: (i) via, (ii) through, (iii) by means of, (iv) as a substitute for, and (v) as a form of 


\section{On+ noun+ of:}

On account of: because of somebody or something.

On (the) ground(s) of: a good or true reason for doing or saying something.

On pain of: with the threat of having something done to you as a punishment if you do not obey.

On the strength of: because somebody has been influenced or persuaded by something= (relying on) or (on the basis of).
On behalf of: (i) instead of them, (ii) in order to help somebody, (iii) as representative of somebody or something (iv) because of somebody, and (v) for somebody.

On the matter of: (i) concerning and (ii) as regard to.

On the part of: made or done by somebody.

On top of: (i) on; over or covering something or somebody, (ii) in addition to something, (iii) very close to something or somebody, and (iv) in control of a situation.

\section{Other types:}

As far as: (i) to the distance of (a place), and (ii) to the extent that.

At the expense of: with loss or damage to somebody or something.

For (the) sake of: (i) out of consideration for, (ii) in the interest of, (iii) because of or owing to, and (iv) in order to please, honour get or keep.

In exchange for: an act of giving something to somebody and receiving something in return.

In addition to: as something added.

With / in regard to: concerning something.

With / in respect to: concerning somebody or something.
At variance with: disagreeing with or opposing somebody or something.

At the hands of: because of somebody or something.

For / from want of: because of a lack of something or because something is not available.

In return for: (i) as a way of thanking somebody, (ii) paying them for something they have done, and (iii) as response or a reaction to something.

In relation to: (concerning or compared with)

With / in reference to: used to say what you're talking or writing about.

With the exception of: except.

\subsection{Prepositional Meanings}

A preposition is used to express a relation between two entities, one is represented by the prepositional complement and the other is represented by another part of the sentence. Relational meaning of space and time can be described systematically. Other relationships such as instrument, cause, and concession may also be recognized, although it is difficult to describe prepositional meanings systematically in terms of such labels (Quirk et al., 1985).

\subsubsection{Prepositions Denoting Spatial Relation}

Prepositions that denote spatial relation can be classified into the following:

\subsubsection{Dimension}

Here, the choice of the preposition depends on the dimension of the object. For instance, a floor is a flat surface and may be deemed as two-dimensional. On the other hand, a room may be considered as three-dimensional. However, it is not the real dimensions of the object, but how the speaker sees or envisages it at the time of speaking, not on how the object can be measured mathematically according to the three dimension types. For example, a wall may be seen as a surface (Leech \& Svartvik, 1975, p. 82) (Shepherd et al., 1991).

3- Go out of the office. (Close, 1975, p. 167)

4- She jumped on to the horse. (Quirk et al., 1985, p. 675)

5- Tom is running away from the hill. (Shepherd et al., 1991, pp. 269)

The compound preposition as far as is used to stress the length of the journey. It refers only to space, but it does not refer to time (Quirk et al., 1985, p. 677). 
6- They drove as far as Edinburgh. (Quirk et al., 1985, p. 677).

7- Go as far as $x$. (Close, 1975, p. 167)

\subsubsection{Negative Position}

The negative prepositions away from and out of may be defined simply by the addition of the word not to their corresponding positive preposition: away from ['not at'] out of ['not in'].

8- Ann is away from home. (Ann is not at home)

9- Tom is out of the water. (Tom is not in the water) (Quirk et al., 1985, p. 678)

\subsubsection{Relative Position}

Apart from simple preposition, prepositions may express relative position between two or more objects. On top of represents relative position vertically (i.e., it denotes that something is above the higher surface of an object), whereas in front of expresses it horizontally (Shepherd et al., 1991, p. 273).

10- We placed the skis on top of the car. (Quirk et al., 1985, p. 678)

11- There's a bus stop in front of the house. (Hornby, 2006, p. 625)

\subsubsection{Space}

The compound prepositions close to, near(er) to, next to are locative prepositions. The simple preposition near, viz. close to can be represented by the compound preposition near to.

12- She was sitting $\left\{\begin{array}{c}\text { near (to) } \\ \text { close (to) }\end{array}\right\}$ me. (Quirk et al., 1985, p. 680)

Near (to) and close to are the only prepositions which can be inflected for comparison unlike absolute form. So we can say nearer to, nearest to, closer to, and closest to (Quirk et al., 1985, p. 680).

13- She was sitting $\left\{\begin{array}{l}\text { nearer (to) / nearest (to)/ next to me. } \\ \text { closer to / closest to me. (Ibid.) }\end{array}\right.$

14- Go and sit nearer to the fire. (Hornby, 2006, p. 1017)

\subsubsection{Resultative Meaning}

Resultative meaning is not always distinguished from other static meaning. However, its presence is often characterized by certain adverbs (already, just, at last, (not) yet, etc.) (Quirk et al., 1985, p. 684).

15- At last we are out of the forest. (Ibid.)

16- At last Mr Green is out of town this week. (Hornby, 2006, p. 1074)

\subsubsection{Metaphorical or Abstract Use}

Many prepositions of place have abstract meanings which are clearly related to their locative uses through metaphorical connection. Such prepositions are used to keep the grouping in terms of similarity or contrast of meaning that they have when used in a literal reference to place (Quirk et al., 1985).

Examples in relation to the literal meanings are the following:

Position $\longrightarrow$ state, condition:

17- To be out of danger, to be out of office, to keep out of trouble, to be out of a job. (Ibid., p. 686)

Enclosure $\longrightarrow$ abstract inclusion:

18- Out of the race. (Ibid.)

Destination $\longrightarrow$ abstract condition or circumstances:

19- Can you get me out of this mess? (Ibid.)

\subsubsection{Prepositions Denoting Time}

The compound preposition up to is used to indicate the starting and the ending of a point in a period. Up to specifies that the longer period does not include the period named in the prepositional complement (Leech \& Svartvik, 1975, pp. 79-80). 
20- We camped there up to September. (Quirk et al., 1985, p. 690)

21- We worked up to Christmas (but not over Christmas).

Informally till can be used with up instead of until (Hewings, 2005, p. 180).

22- I've just bought a computer. I've always used a typewriter up $\left\{\begin{array}{c}\text { to } \\ \\ \text { till }\end{array}\right\}$ now. (Ibid.)

23- The roadworks are likely to go on up $\left\{\begin{array}{c}\text { to } \\ \text { till }\end{array}\right\}$ the end of May. (Ibid.)

\subsubsection{Cause, Reason, Motive}

Such prepositions may express the material cause or the psychological cause (motive) for a happen. Phrases of cause, reason and motive answer the question why...?

24- We had to drive slowly because of the heavy rain.

25- On account of his wide experience, he was made chairman.

26- Some support charities out of duty, some out of a sense of guilt. (Quirk et al., 1985, pp. 695-696)

The compound prepositions on account of and because of can be used interchangeably and it is restricted to the expression of cause or reason, while out of is mainly restricted to the expression of motive, i.e., psychological cause: out of gratitude / kindness / etc. (ibid.).

The compound prepositions due to and owing to are used to show a reason for something (Hewings, 2005, p. 160).

27- She was unable to run owing to / due to a leg injury. (=because of a leg.)

28- We have less money to spend owing to / due to budget cuts. (=because of budget cuts.)

"In current English we usually avoid owing to directly after a form of be" (ibid.).

29- The company's success is due to the new director. (not... is owing to...)

However, owing to is preceded by the verb be + an adverb such as entirely, largely, mainly, partly (ibid.).

30- The low election turnout was partly due to / owing to the bad weather. (Ibid.).

We can often say either it was due to ... that or it was owing ... that.

31- It was owing to his encouragement that she applied for the job (or it was due to... that) (Hewings, 2005, p. 160).

\subsubsection{Concession}

The compound preposition in spite of is a general-purpose preposition of concession.

32- I admire him, in spite of his faults. (Quirk et al., 1985, p. 705)

33- In spite of his age, he still leads an active life. (Hornby, 2006, p. 1476)

\subsubsection{Respect}

Some compound prepositions that refer to respect are employed in the context of business letters.

34- With reference to [less usual: In reference to] your letter / request /enquiring of April $29^{\text {th }}$, I confirm my Directors' agreement to advance a further sum of $£ 2000$. (formal)

35- With regard to the date of delivery ... [less usual In regard to; typically introducing a secondary or tertiary topic in such a letter] (Quirk et al., 1985, p. 705).

The prepositions have the same area of meaning: with respect to, in respect of, on the matter of, and as to (ibid.).

The compound preposition as to means on the subject of (Close, 1975, p. 177). It functions like with regard to, as regards, etc (Quirk et al., 1985, p. 706).

36- As to the question you raise in your last letter, I think that ... (ibid.) 
37- No agreement was reached $\left\{\begin{array}{l}\text { as to } \\ \text { =concerning }\end{array}\right\}\left\{\begin{array}{l}\text { rent } \\ \text { how much we should pay. (Close, 1975, p. 177) }\end{array}\right.$

"As to is also used in the sense of according to, e.g.: correct as to size and colour" (Quirk et al., 1987, p. 706).

On the other hand, as for means speaking of or with reference to (Close, 1975, p. 177). This preposition introduces a topic transition, so it cannot be used at the beginning of a discourse. It has the meaning of 'returning to the question of', and is less formal than the other compound prepositions denoting respect (Quirk et al., 1985, pp. 706-707).

38-I don't blame George. As for John, he has behaved so badly. (Close, 1975, p. 177)

39- We had a delightful weekend in the country. As for the traffic, we had no difficulty. (Quirk et al., 1985, p. 707)

Sometimes, the preposition as for occurs initially to indicate a scornful attitude.

40- As for his book, I supposed you've read the reviews! (Ibid.)

41- As for Jo, she's doing fine. (Hornby, 2006, p. 74)

\subsubsection{Exception}

The compound prepositions that show exception are: except for, with the exception of, apart from, aside from $<$ esp AmE $>$. When used in adverbials, prepositions denoting exception function primarily as disjuncts.

42- With the exception of James, none of us had any money.

43- The worst period of my life, $\left\{\begin{array}{l}\frac{\text { apart from the war }}{\text { aside from }} \text { the war }<\mathrm{esp} \mathrm{AmE}>\end{array}\right\}$ was when I was out of

work. (Quirk et al., 1985, p. 707)

44- Except for George, you can all go. (Close, 1975, p. 178)

3.1.7 Addition

Addition can be expressed by the following compound prepositions: in addition to and as well as.

45- There were three people present in addition to the committee. (Quirk et al., 1985, p. 708)

46- You can go as well as George. (Close, 1975, p. 177)

\subsubsection{Negative Condition}

The preposition but for is not used for the purpose of exception but it is rather used for the purpose of negative condition.

47- But for Gordon, we would have lost the match. ['If it hadn't been for Gordon...', 'If Gordon hadn't played as he did...,' etc] (Quirk et al., 1985, p. 709)

It is thought that except for works like but for to denote a negative condition. However, except for normally denotes exception. The following two sentences are different in their meanings:

48- Except for John they $\left\{\begin{array}{l}\text { would all have died. ['If it hadn't been for John...'] } \\ \text { all died. ['With the exception of John...'] (Ibid.) }\end{array}\right.$

49- He would have played but for a knee injury. (Hornby, 2006, p. 204)

3.1.9 Material, Ingredient

The compound preposition out of signifies the material or constituency of the whole thing.

50- He made the frame out of wood. ['Wood was the only material.'] (Quirk et al., 1985, pp. 710-711)

\subsection{Modification of Prepositional Phrase}

Prepositional meanings (especially of time and place) are subject to modification as regards degree and measure. A preposition may be preceded by an intensifier like many adjectives and adverbs.

51- This cake mix comes straight $<$ out of $\geq$ the packet. 
52- The dog was lying right $<$ in the middle of $>$ the floor. (Quirk et al., 1985, p. 713)

There is a doubt in such cases whether the intensifier is related to the whole prepositional phrase or to the preposition alone. In the example above, the intensifier can modify the prepositional adverb: right in the middle (ibid.).

\subsection{Preposition and Prepositional Adverbs}

A prepositional adverb is a particle which is formally related to a preposition, and which often behaves like a preposition with ellipted complement:

53- A car drove $\left\{\begin{array}{l}\text { past the door. [Past is a preposition] } \\ \text { past. [Past is a prepositional adverb] (Quirk et al., 1985, p. 713) }\end{array}\right.$

Thus, a prepositional adverb shares the form of a preposition, but it is syntactically different. The prepositional adverb can stand alone as an adjunct, conjunct, postmodifier and without the addition of a prepositional complement:

54- Despite the fine weather, we stayed in all day. (Ibid.)

Prepositions and adverbs combine with a preceding verb e.g.: make up for (Ibid., p. 714).

The following list includes some prepositional adverbs related to compound (three-word) prepositions.

55- Why don't you put the trunk $\left\{\begin{array}{l}\text { on top of the car? } \\ \text { on top? (Ibid., p. 715) }\end{array}\right.$

at variance in addition in aid

in case in charge in common

in comparison in context in charge

in favour in front in lieu

in line in need in relation

in return on top

"Prepositional phrases and prepositional adverbs can be seen as the extremes on a scale with a stepwise reduction in explicitness as we proceed from [56] to [60]. In the sentence pattern 'They are all...' we can have:"(Ibid.)

56- in (great) favour of the proposal

57- (greatly) in favour of the proposal

58- (greatly) in favour of it

59- (greatly) in its favour

60- (greatly) in favour

We have in [56] a free syntactic noun phrase with favour as head which admits adjectival premodification; in [57] a compound preposition in favour of with the proposal as complement; in [58] the pronominal substitute for the nominal complement in [57]; in [59] a possessive determiner its; and in [60] the prepositional adverb in favour, which relies for its interpretation on previous mention in the linguistic or situational context. The reduction in [59] (premodification) as compared with [57] and [58] (postmodification) is dealt with in connection with the noun phrase. The step from [59] to [60] is one step beyond premodification structure (Quirk, et al., 1985).

\section{Data Collection}

A diagnostic test is designed so as to find out the difficulties that Iraqi EFL university students face. The test encompasses four questions (see Appendix I). The first question (henceforth Q.I) measures the ability of the subjects to give examples about a given group of compound prepositions. In the second question (Q.II), these learners are required to underline compound prepositions. The third question (Q.III) asks the subjects to fill in the blanks with the most appropriate compound prepositions. In the fourth question (Q.IV) the learners are required to select the right functions of such prepositions from a list. Lastly, each question in the test contains ten items. 
Most the items of the test are taken from An Introductory English Grammar by Norman C. Stageberg (1981), A Comprehensive Grammar of the English Language by Randolph Quirk; Sidney Greenbaum; Geoffrey Leech \& Jan Svartvik (1985), and Oxford Advanced Learner's Dictionary by A S Hornby (2006).

\section{Data Analysis}

This part of the study is concerned with the analysis of the outcomes of the test. It elucidates the errors committed by Iraqi EFL university students and the reasons behind these errors. Furthermore, it presents the students' performance at each question in the test in particular and at the entire test in general.

The following table shows the subjects' performance in Q.I.

Table 3. Participants' abilities in putting compound prepositions in grammatical sentences

\begin{tabular}{c|cccc}
\hline No. of Item & $\begin{array}{c}\text { No. of Correct } \\
\text { Responses }\end{array}$ & $\mathbf{\%}$ & $\begin{array}{c}\text { No. of Incorrect } \\
\text { Responses }\end{array}$ & $\%$ \\
\hline $\mathbf{1}$ & 70 & $70 \%$ & 30 & $30 \%$ \\
$\mathbf{2}$ & 60 & $60 \%$ & 40 & $40 \%$ \\
$\mathbf{3}$ & 45 & $45 \%$ & 55 & $55 \%$ \\
$\mathbf{4}$ & 35 & $35 \%$ & 65 & $65 \%$ \\
$\mathbf{5}$ & 18 & $18 \%$ & 82 & $82 \%$ \\
$\mathbf{6}$ & 10 & $10 \%$ & 90 & $90 \%$ \\
$\mathbf{7}$ & 43 & $43 \%$ & 57 & $57 \%$ \\
$\mathbf{8}$ & 16 & $16 \%$ & 84 & $84 \%$ \\
$\mathbf{9}$ & 7 & $7 \%$ & 93 & $93 \%$ \\
$\mathbf{1 0}$ & 27 & $27 \%$ & 73 & $73 \%$ \\
\hline Total & 331 & $33.1 \%$ & 669 & $66.9 \%$ \\
\hline
\end{tabular}

Table (3) shows that the total number of their correct responses (33.1\%) is lower than that of the incorrect ones $(66.9 \%)$. Consequently, Iraqi EFL learners face real difficulties in producing this sort of prepositions.

Table 4. Participants' abilities in identifying the compound prepositions in a given group of sentences

\begin{tabular}{c|cccc}
\hline $\begin{array}{c}\text { No. of } \\
\text { Item }\end{array}$ & $\begin{array}{c}\text { No. of Correct } \\
\text { Responses }\end{array}$ & $\mathbf{\%}$ & $\begin{array}{c}\text { No. of Incorrect } \\
\text { Responses }\end{array}$ & $\mathbf{\%}$ \\
\hline $\mathbf{1}$ & 49 & $49 \%$ & 51 & $51 \%$ \\
$\mathbf{2}$ & 47 & $47 \%$ & 53 & $53 \%$ \\
$\mathbf{3}$ & 24 & $24 \%$ & 76 & $76 \%$ \\
$\mathbf{4}$ & 43 & $43 \%$ & 57 & $57 \%$ \\
$\mathbf{5}$ & 28 & $28 \%$ & 72 & $72 \%$ \\
$\mathbf{6}$ & 65 & $65 \%$ & 35 & $35 \%$ \\
$\mathbf{7}$ & 31 & $31 \%$ & 69 & $69 \%$ \\
$\mathbf{8}$ & 60 & $60 \%$ & 40 & $40 \%$ \\
$\mathbf{9}$ & 37 & $37 \%$ & 63 & $63 \%$ \\
$\mathbf{1 0}$ & 20 & $20 \%$ & 80 & $80 \%$ \\
\hline Total & 404 & $40.4 \%$ & 596 & $59.6 \%$ \\
\hline
\end{tabular}

Table (4) exhibits that the total number of their correct responses $(40.4 \%)$ is lower than that of the incorrect ones $(59.6 \%)$. This verifies the second hypothesis that reads: Most of them do not recognize the position of compound 
prepositions.

Table 5. Participants' abilities in filling the spaces with suitable compound prepositions

\begin{tabular}{c|cccc}
\hline No. of Item & $\begin{array}{c}\text { No. of Correct } \\
\text { Reponses }\end{array}$ & $\%$ & $\begin{array}{c}\text { No. of Incorrect } \\
\text { Responses }\end{array}$ & $\%$ \\
\hline $\mathbf{1}$ & 6 & $6 \%$ & 94 & $94 \%$ \\
$\mathbf{2}$ & 18 & $18 \%$ & 82 & $82 \%$ \\
$\mathbf{3}$ & 29 & $29 \%$ & 71 & $71 \%$ \\
$\mathbf{4}$ & 10 & $10 \%$ & 90 & $90 \%$ \\
$\mathbf{5}$ & 25 & $25 \%$ & 75 & $75 \%$ \\
$\mathbf{6}$ & 35 & $35 \%$ & 65 & $65 \%$ \\
$\mathbf{7}$ & 20 & $20 \%$ & 80 & $80 \%$ \\
$\mathbf{8}$ & 16 & $16 \%$ & 84 & $84 \%$ \\
$\mathbf{9}$ & 41 & $41 \%$ & 59 & $59 \%$ \\
$\mathbf{1 0}$ & 5 & $5 \%$ & 95 & $95 \%$ \\
\hline Total & 205 & $20.5 \%$ & 795 & $79.5 \%$ \\
\hline
\end{tabular}

From the table above the total number of the incorrect responses $(79.5 \%)$ is higher than that of the correct ones $(20.5 \%)$.

Table 6. Participants' abilities in identify the function of a given compound prepositions from a list

\begin{tabular}{c|cccc}
\hline No. of Item & $\begin{array}{c}\text { No. of Correct } \\
\text { Reponses }\end{array}$ & $\mathbf{\%}$ & $\begin{array}{c}\text { No. of Incorrect } \\
\text { Responses }\end{array}$ & $\%$ \\
\hline $\mathbf{1}$ & 67 & $67 \%$ & 33 & $33 \%$ \\
$\mathbf{2}$ & 16 & $16 \%$ & 84 & $84 \%$ \\
$\mathbf{3}$ & 40 & $40 \%$ & 60 & $60 \%$ \\
$\mathbf{4}$ & 85 & $85 \%$ & 15 & $15 \%$ \\
$\mathbf{5}$ & 39 & $39 \%$ & 61 & $61 \%$ \\
$\mathbf{6}$ & 8 & $8 \%$ & 92 & $92 \%$ \\
$\mathbf{7}$ & 11 & $11 \%$ & 89 & $89 \%$ \\
$\mathbf{8}$ & 18 & $18 \%$ & 82 & $82 \%$ \\
$\mathbf{9}$ & 3 & $3 \%$ & 97 & $97 \%$ \\
$\mathbf{1 0}$ & 65 & $65 \%$ & 35 & $35 \%$ \\
\hline Total & 352 & $35.2 \%$ & 648 & $64.8 \%$ \\
\hline
\end{tabular}

It is clear, from the results above, that the total number of the incorrect responses $(64.8 \%)$ is higher than that of the correct ones (35.2\%). This assures the third hypothesis which reads: Most of them do not know how to recognize the function of such prepositions. In a word, they do not discern the function of compound prepositions (i.e., place, time, cause, reason, concession, respect, material, exception, and addition). 
Table 7. Participants' performance at the production level

\begin{tabular}{c|cccc}
\hline No. of Question & $\begin{array}{c}\text { No. of Correct } \\
\text { Responses }\end{array}$ & $\%$ & $\begin{array}{c}\text { No. of Incorrect } \\
\text { Responses }\end{array}$ & $\%$ \\
\hline $\mathbf{1}$ & 331 & $33.1 \%$ & 669 & $66.9 \%$ \\
$\mathbf{3}$ & 205 & $20.5 \%$ & 795 & $79.5 \%$ \\
Total & 536 & $26.8 \%$ & 1464 & $73.2 \%$ \\
\hline
\end{tabular}

Table (7) illustrates that the total number of the wrong answers (73.2\%) is more than that of the right answers $(26.8 \%)$. This shows that they encounter real difficulties at the production level.

Table 8. Participants' performance at the recognition level

\begin{tabular}{c|cccc}
\hline No. of Question & $\begin{array}{c}\text { No. of Correct } \\
\text { Responses }\end{array}$ & $\%$ & $\begin{array}{c}\text { No. of Incorrect } \\
\text { Responses }\end{array}$ & $\%$ \\
\hline $\mathbf{2}$ & 404 & $40.4 \%$ & 596 & $59.6 \%$ \\
$\mathbf{4}$ & 352 & $35.2 \%$ & 648 & $64.8 \%$ \\
Total & 756 & $37.8 \%$ & 1244 & $62.2 \%$ \\
\hline
\end{tabular}

Table (8) elucidates that the total number of the wrong answers $(62.2 \%)$ is more than that of the right answers $(37.8 \%)$. This shows that they also encounter real difficulties in recognizing this sort of prepositions, but they face more difficulties in producing them. This validates the first hypothesis which says: Most Iraqi EFL university students encounter difficulties in recognizing and producing compound prepositions.

The following table shows subjects' achievement in the whole test.

Table 9. Subjects' achievement of the entire test

\begin{tabular}{c|cccc}
\hline No. of Question & $\begin{array}{c}\text { No. of Correct } \\
\text { Responses }\end{array}$ & $\%$ & $\begin{array}{c}\text { No. of Incorrect } \\
\text { Responses }\end{array}$ & $\%$ \\
\hline $\mathbf{1}$ & 331 & $33.1 \%$ & 669 & $66.9 \%$ \\
$\mathbf{2}$ & 404 & $40.4 \%$ & 596 & $59.6 \%$ \\
$\mathbf{3}$ & 205 & $20.5 \%$ & 795 & $79.5 \%$ \\
$\mathbf{4}$ & 352 & $35.2 \%$ & 648 & $64.8 \%$ \\
\hline Total & 1292 & $32.3 \%$ & 2708 & $67.7 \%$ \\
\hline
\end{tabular}

The results indicate that the total number of the incorrect responses $(67.7 \%)$ is lower than that of the correct ones (32.3\%). This indicates that Iraqi EFL university students face real difficulties in recognizing and producing compound prepositions. This proves the fourth hypothesis which states: Most of them generally flunk to acquire the proper use of compound prepositions.

\section{Sources of Errors}

Errors sound as inevitable part of language learning (Thornbury, 2000). Traditionally, errors were deemed as the negative part of language learning and they had to be eschewed or eradicated. Recently, errors are regarded as natural processes of language learning, (Yule, 2006).

According to Brown (1987), learners' errors are attributed to interlingual transfer, intralingual transfer, context of learning, and communication strategies. The tool for identifying and understanding the sources of errors rests on the nature of errors that involves the existence of reasons for errors that occur (Erdoğan 2005).

\subsection{Interlingual Transfer}

This kind of error occurs due to the effect of Iraqi EFL university students' mother tongue language on the foreign one (Brown, 2001). 
Some of the errors in items (6) and (10) of Q.I can reflect the influence of the mother tongue.

Item (6): I speak with respect to my teacher.

Item (10): This is not for reading but for writing.

Obviously, some participants translate the compound prepositions from English into Arabic and they give the meaning of each word in the compound preposition separately in lieu of treating it as a unit. They do such a thing because they do not know the meaning of such prepositions as a unit. Some subjects translate with respect $\boldsymbol{t o}$ as a feeling of admiration for somebody or something (أنكلم باحترام دع أستاذي) in place of concerning somebody or something. On the other hand, some subjects think that but for is used here for exception ( هذا ليس للقراءة ولكن ) للكنابة), whereas it means if it were not for (لو لابة).

\subsection{Intralingual Transfer}

This type of errors happens owing to improper or partial learning of the foreign language. Such errors may be the result of the influence of one language item upon another (Penny, 2001).

Intralingual errors encompass the following:

Overgeneralization error: It involves the incorrect application of the previously learned second language material to a present second language context (Brown, 1987).

Ignorance of rule restriction: it means "applying rules to contexts to which they do not apply" (Richards \& Sampson, 1974, p. 70).

Incomplete application of the rules: These result from "failure to use certain target language structures because they are thought to be too difficult" (Richards \& Schmidt, 2002, p. 185).

False concepts hypothesized: these may derive from wrong comprehension of a distinction in the target language (Brown, 1987) and (Chanier et al., 1992).

Overgeneralization errors emerge in items (5) and (9) of Q.II.

Item (5): As to tax, that will be deducted from your salary.

Item (9): she was away from work for a week.

The items above elucidate that Iraqi EFL university students overgeneralize the rule because they envisage that each preposition following or preceding the compound preposition is part of it. Most of them do not discern that compound prepositions can be divided into two or three-word sequences prepositions.

Ignorance of rule restrictions is another reason behind subjects' errors in items (2) and (5) of Q.I.

Item (2): I bought the car at the expense of $30000 \$$.

Item (5): I'll stand up against him.

In the answers above, the students use idioms and phrasal verbs in place of the compound prepositions.

Similarly, in Q.II, some of the errors may be also ascribed to ignorance of rule restrictions.

Item (1): A statue is made out of the bronze.

Item (3): Britain, in common with many other industrialized countries, has experienced major changes of the last 100 years.

Here, the students have underlined one preposition assuming it to be the compound preposition.

As for incomplete application of rules, some of the errors in item (9) of Q.IV and item (9) of Q.I may be attributed to.

Item (9): You can go as well as George. (*similarity or comparison)

Item (9): On account of Susan, she should stay here. (*on account of means concerning)

False concept hypothesized may be also the reason behind some of the subjects' incorrect responses to certain items in Q.IV as in the following examples:

Item (6): The company's position with regard to overtime is made clear in their contracts. (*time)

Item (3): I've always used the net up till now. (*manner)

Here, the subjects have concluded the meaning of compound prepositions from the meaning of the sentences.

\subsection{Context of Learning}

This sort of errors arises from faulty methods of teaching or syllabus designers who concentrate on some aspects 
of the language and neglect others according to their belief or experiences (Brown, 1987).

It is worth mentioning that compound prepositions receive little focus in grammar textbooks and other books of grammar. Even the writers of these books do not devote enough exercises or examples about such prepositions. Most of them give list of them without giving enough explanations about their meanings or uses. As such, the teachers do not focus on these prepositions and do not use them extensively.

The errors in item (8) of Q.II, item (1) of Q.III, and item (2) of Q.IV may be attributed to the context of learning.

Item (8): We worked up to Christmas.

Item (1): There was nothing they could do, in place of hoping things would get better.

Item (2): In spite of her protestation, Harriet was persuaded to join the guild. (*time)

\subsection{Communication Strategies}

In this section, some of the communication strategies which are used by the participants of this study are:

Avoidance: Learners sometimes shun the items which they perceive to be difficult for them (Lightbown \& Spada, 2003).

In item (7) of Q.IV, some students have avoided this item.

Creating New Words or Coinage: The learner may create or invent new words or phrases so as to express the desired idea (Faucette, 2001).

Some of the errors in item (4) and (10) of Q.IV may be ascribed to coinage.

Item (4): He made the cupboard out of wood. (*purpose or *manner)

Item (10): Our fax number is changing as from May 12. (*contrast)

Guessing: When the learners are in doubt about the correct answer, they begin to guess (Brown, 2001). Most of the incorrect response of Q.III might be attributed to guessing.

\section{Conclusions}

The majority of Iraqi EFL university students face more difficulty in producing and recognizing compound prepositions as the total number of their correct responses $(26.8 \%)(37.8 \%)$ is lower than that of the incorrect ones $(73.2 \%)(62.2 \%)$. This verifies the first hypothesis.

In addition, most of them do not recognize the position of compound prepositions because they envisage that each preposition following or preceding the compound preposition is related to it. Consequently, the total number of their incorrect responses (59.6\%) is higher than that of the correct ones (40.4\%). This validates the second hypothesis.

Most of Iraqi EFL university students encounter difficulties in recognizing the function of compound prepositions as the total number of the correct responses (35.2\%) is lower than that of the incorrect ones (64.8\%). This assures the third hypothesis.

Furthermore, most of them fail to acquire compound prepositions correctly. For this reason, the total number of the correct responses $(32.3 \%)$ is lower than that of the incorrect ones $(67.7 \%)$. This indicates that Iraqi EFL university students face real difficulties in recognizing and producing compound prepositions. This proves the fourth hypothesis.

The majority of textbook writers and syllabus designers do not give the meanings of compound prepositions. For this reason, many EFL university students are easily liable to commit mistakes when they employ this sort of prepositions because they do not know their meanings as well as their functions.

Actually, there are three sorts of errors committed by the sample of the study. These errors can be summarized as follows: (a) wrong recognition of compound prepositions, (b) incorrect production of such prepositions, (c) giving no answer.

Hence, the subjects' errors are attributed to the following factors: (i) interlingual transfer, whereby the subjects use Arabic literal meaning separately for each word in the compound prepositions rather than giving the meaning for them as a whole, (ii) intralingual transfer, whereby the subjects use their prior knowledge of the target language, (iii) context of Learning, as little attention is paid to such prepositions by textbook writers and instructors, and (iv) communication strategies which are selected by the subjects to fill the gap of their knowledge. 


\section{References}

Brown, D. (1987). Principles of language learning and teaching (2 nd ed.). Englewood Cliffs: Prentice Hall, Inc.

Brown, H. D. (2001). Teaching by principles: An interactive approach to language pedagogy (2nd ed.). San Francisco: Longman, Inc.

Chalker, S. (1989). Current English grammar. London: Macmillan Publishers Ltd.

Chanier, T., Pengelly, M., \& Self, J. (1992). Conceptual modelling in error analysis in computer-assisted language learning system. $\quad$ Retrieved from http://www.kkhec.ac.ir/Linguistics20\%articles\%20index\%Conceptual\%Modelling\% 20\%in\%20Error\%20Analysis.htm

Close, R. A. (1975). A reference grammar for students of English. London: Longman Group Limited.

Crystal, D. (2003). The Cambridge encyclopedia of the English language (2nd ed.). Cambridge: Cambridge University Press.

Erdoğan, V. (2005). Contribution of error analysis to foreign language teaching. Retrieved from http://efd.mersin.edu.tr/dergi/meuefd_2005_001_002/pdf/meuefd_2005_001_002_0261-0270_erdogan.pdf

Faucette, P. (2001). A pedagogical perspective on communication strategies: Benefits of training and an analysis of English language teaching materials. Retrieved from http://www.hawaii.edu/sls/uhwpesl/19(2)/Faucette.pdf.

Hewings, M. (2005). Advanced grammar in use. Cambridge: Cambridge University Press.

Hornby, A. S. (2006). Oxford advanced learner's dictionary of current English. Oxford: Oxford University Press.

Huddleston, R. (1985). Introduction to the grammar of English. Cambridge: Cambridge University Press.

Japkowicz, N., \& Wiebe, J. M. (2009). A system for translating locative prepositions from English into French (1991). Proceedings of the 29th Annual Conference of the ACL. Retrieved from http://citeseerx.ist.psu.edu/viewdoc/summary?doi=10.1.1.39.9897

Leech, G., \& Svartvik, J. (1975). A communicative grammar of English. London: Longman.

Lightbown, P. M., \& Spada, N. (2003). How languages are learned. Oxford: Oxford University Press. http://dx.doi.org/10.1080/09571730385200151

Mahmoodzadeh, M. (2012). A cross-linguistic study of prepositions in Persian and English: The effect of transfer. Theory and Practice in Language Studies, 2(4), 734-740. http://dx.doi.org/10.4304/tpls.2.4.734-740

Meurant, R. C. (2007). Are English prepositions simply degenerate verbs? Paper presented at the 2007 International Conference on Convergence Information Technology, Gyeongju. ICCIT, pp. 750-756. Retrieved from http://homepage.mac.com/rmeurant/

Oliveira, C., \& Garrão, M. (2009). Recognising complex prepositions Prep+N+Prep as negative patterns in automatic term extraction from texts. In TIL'2003 - $1^{\circ}$ Workshop em Tecnologia da Informação $e$ Linguagem Humana, evento associado ao XVI Brazilian Symposium on Computer Graphics and Image $\begin{array}{llll}\text { Processing } & \text { - } & \text { (SIBGRAPI). } & \text { Retrieved }\end{array}$ http://www.nilc.icmc.usp.br/til2003/oral/oliveira_garrao_amaral25.pdf

Palmer, H. E., \& Blandford, F. G. (1976). A grammar of spoken English (3rd ed.). London: Cambridge University Press.

Penny, W. K. (2001). An analysis of student error patterns in written English: Suggested teaching procedures to help. Retrieved from http://www.cels.bham.acuk/resources/essays/penny2.pdf

Quirk, R., Greenbaum, S., Leech, G., \& Svartivik, J. (1985). A comprehensive grammar of the English language. London: Longman.

Richards, J. C., \& Sampson, G. P. (1974). The study of learner English. In J. C. Richards (Ed.), Error analysis. perspectives on second language acquisition. London: Longman.

Richards, J. C., \& Schmidt, R. (2002). Dictionary of language teaching and applied linguistics. London: Pearson Education Limited.

Robert, P. (1956). Patterns of English. New York: Harcourt, Brace and World Inc.

Shepherd, J., Rossner, R., \& Taylor, J. (1991). Ways to grammar. London: Macmillan Ltd. 
Shih, C. (2012). A corpus-aided study of shifts in English-to-Chinese translation of prepositions. International Journal of English Linguistic, 2(6). http://dx.doi.org/10.5539/ijel.v2n6p50

Stageberg, N. C. (1981). An introductory English grammar. Fort Worth: Holt, Rinehart and Winston, Inc.

Thornbury, S. (2000). How to teach grammar. Essex: Longman.

Trawiński, B. (2008). A new application for raising in HPSG: Complex prepositions. In G. Penn (Ed.), Proceedings of FGVienna: The 8th Conference on Formal Grammar (pp. 139-152). Stanford: CSLI Publications.

van de Vate, M. (2006). "Prepositions in Krio", Nordlyd. Tromsø University working papers on language \& linguistics. Retrieved from http://septentrio.uit.no/index.php/nordlyd/article/view/83

Yule, G. (2006). The study of language (3rd ed.). Cambridge: Cambridge University Press.

\section{Appendices}

\section{Appendix I}

\section{The Test}

Q.I/ Put the following compound prepositions in grammatical sentences.

Example: They are here because of the problem.

1) in contact with 2) at the expense of 3) previous to 4) along with 5) up against 6) with respect to 7) contrary to 8) except for 9) on account of 10) but for

Q.II/ Underline the compound prepositions.

Example: They collected the money in behalf of the homeless.

1- A statue is made out of bronze.

2- He was unable to walk due to a leg injury..

3- Britain, in common with many other industrialized countries, has experienced major changes over the last 100 years.

4- All his novels are set in Italy with the exception of his last.

5 - As to tax, that will be deducted from your salary.

6- As for food for the party, that's all being taken care of.

7- The game was cancelled owing to torrential rain.

8- We worked up to Christmas.

9- She was away from work for a week.

10- I got the job on the strength of your recommendation.

Q.III/ Write the appropriate compound preposition that best fills in the blank.

Example: There have been further developments subsequent to our meeting.

1-There was nothing they could do, hoping thing would get better.

2- The sky was the clouds.

3- You can use milk cream in this recipe.

$4-$ the weather, the event will now beheld indoors.

5- He succeeded hard work.

6- He was sitting them.

7- These conclusions are totally the evidence.

8- I have some comments to make this matter.

9- Would you like my old TV this camera?

10 - I sent them my order, a cheque for $£ 40$.

Q.IV/Identify the function of the following compound prepositions from the list below:

(duration, dimension, time, concession, reason or cause, exception, addition, locative, respect, material, 
negative condition)

Example: She was sitting nearer to Oliver. Locative preposition or Preposition of place

1 - She jumped on to the fence.

2- In spite of her protestation, Harriet was persuaded to join the guild.

3- I've always used the net up till now.

4- He made the cupboard out of wood.

5- Janet was standing close to me.

6- The company's position with regard to overtime is made clear in their contracts.

7 - We had no trouble on the journey apart from a flat tyre.

8- It was all a great success thanks to a lot of hard work.

9- You can go as well as George.

10- Our fax number is changing as from May 12.

\section{Appendix II}

Suggested Answers to the Test

Answers of Q.I:

1- The organization put me in contact with other people in a similar position.

2- He built up the business at the expense of his health.

3- Previous to this, she'd always been well.

4- She lost her job when the factory closed, along with hundreds of others.

5- Teachers are up against some major problems these days.

6- The two groups were similar with respect to income and status.

7- Contrary to our expectations, the movie was a delightful spoof.

8- I had nothing on except for my socks.

9- The game was called off on account of rain.

10- He would have played but for a knee injury

Answers of Q.II:

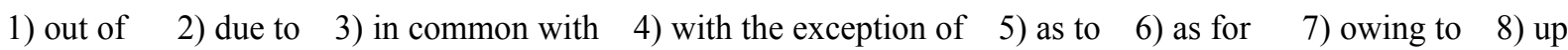
to 9) away from 10) on the strength of

Answers of Q.III:

1- outside of 2- void of 3-in place of 4- in view of 5- by dint of 6- next to 7- at variance with 8- in relation to 9in exchange for 10- together with.

Answers of Q.IV:

1-Dimension 2- concession 3- duration 4- material 5- locative 6- respect 7- exception 8- reason or cause 9addition 10- time 